\title{
Synthesis and Characterization of Palladium (II) Complexes Containing Mixed Ligands with Pyrrolidine Dithiocarbamate and Phosphines
}

\author{
Mousa. S. Hussein \\ Directorate General Education of Diyala, Iraq. \\ Corresponding Author: Musachem80@Gmail.Com.
}

\begin{abstract}
This work includes preparation and characterization of new four mono nuclear complexes of palladium metal ion result from treating palladium chloride with ammonium pyrrolidine dithiocarbamate (PDTC), tertiary phosphines(dppe, dppp) and 2-phenyl pyridine (Hppy) in different molar ratios. All complexes have been characterized by spectroscopic methods $\{$ IR, UV-Vis, ${ }^{1}$ HNMR \} spectroscopy, in addition to elemental analysis (C.H.N) and conductivity measurement. pyrrolidine dithiocarbamate ligand behaves like bidentate in the complexes [Pd(PDTC)(dppe)]Cl and $[\operatorname{Pd}(\mathrm{PDTC})(\mathrm{ppy})]$ but it behaves as mono dentate in the complexes $\left[\operatorname{Pd}(\mathrm{PDTC})_{2}(\mathrm{dppp})\right]$ and $\left[\operatorname{Pd}(\mathrm{PDTC})_{2}(\mathrm{dppe})\right]$, while tertiary phosphines and 2-phenyl pyridine behave like bidentate ligand.

[DOI: 10.22401/JNUS.21.2.03]
\end{abstract}

Keywords: palladium, pyrrolidine dithiocarbamate, phosphines.

\section{Introduction}

The copper and zinc complexes with pyrrolidine dithiocarbamate works as antiviruses drug $[1, r]$. Dupont [3] and his assistants explain effectiveness of some diethicarbamic acid derivatives in the elimination of fungus and bacteria (Antifungicid and Antibacterial activity) [4,5]. Dithiocarbamate used in agriculture as insecticides [6-8]. They are also used in vulcanization of rubber liners [8,9]. and in the concentration of sulphide ores by froth floatation process for concentration of sulphide ores, it was also used as lubricants and antioxidants [9], and in solar cell regeneration technology [10], and also known as anticancer agents [6]. Josh Ghosh and his associates were also able to prepare the vanadium complexes with thiocarbamate used as a contraceptive method [11]. Pyrrolidinedithiocarbamate (PDTC) is used as an antiviruses that cause influenza by defeat of the gene responsible for the formation of this virus [12,13]. while the Bis (dip henyphosphino)ethane (dppe) and Bis (diph enyphosphino)propan (dppp) behave as bidentate chelate [14] or behave as bridge ligands between two metal atoms [5,15], the complexes of phosphine with palladium used as assistant agent cyclic or heterocyclic by increase stability of medial compound [16] and used in olefins polymer [17], 2-phenyl pyridine (ppy) is heterocyclic organic compound ligands [18,19] is metelated and coordinated as chelate through the carbon atom of the phenyl ring and the $\mathrm{N}$ atom of the pyridine ring, it easy to be complex with palladium [20], also (ppy) used in fabrication of electroluminescent devices at laboratory scale as phosphorescent [21], there are a lot of complexes for (ppy) with palladium we can find in literary [21-23].

\section{Experimental}

\subsection{Physical Measurements and Analysis}

The ${ }^{1} \mathrm{H}$ NMR spectra were recorded on a Varian Unity spectrometer in $\mathrm{CDCl} 3$ or $\mathrm{d}^{6}$ dmso. while FT-IR spectra were taken on a Shimidzu FT-IR 8400 spectrophetometer in range $400-4000 \mathrm{~cm}^{-1}$ range using $\mathrm{KBr}$. Electronic spectra were obtained using UV-vis 1650PC Spectrophotometer at room temperature in DMSO solvent. Elemental analysis was recorded using a Euro vector EURO EA 300 elemental analyzer.while Melting points recorded on a Gallenkamp melting point apparatus. Condu-ctivity measurements were carried out on $0.001 \mathrm{M}$ solutions using a digital conductivity meter.

\subsection{Chemicals}

$\mathrm{PdCl}_{2}, \quad$ Pyrrolidine dithiocarbamate (PDTC) prepared by Sigma company, 2phenylpyridine (ppy) Prepared by a Aldrich company, Bis (diphenyphosphino)ethane (dppe), Bis (diph enyphosphino)propan (dppp) 
Prepared by BDH company, were purchased and used us received. The complexes $[\mathrm{Pd}(\mathrm{PDTC}) \mathrm{Cl}]_{\mathrm{n}}(\mathrm{n}=1-2)$ preparation was according to literature published in [24], while $\left[\mathrm{Pd}_{2}(\mathrm{ppy})_{2}(\mu-\mathrm{Cl})_{2}\right]$ in literature published in [21].

\subsection{Preparation of Complexes 1- [Pd(PDTC)(dppe)]Cl}

A (dppe) $(0.065 \mathrm{~g}, 0.163 \mathrm{mmol})$ dissolved in $\mathrm{CHCl}_{3}(10 \mathrm{ml})$ was add to a Solution of [Pd(PDTC)Cl] $\quad(0.050 \mathrm{~g}, 0.170 \mathrm{mmol}) \quad$ in $\mathrm{CHCl}_{3}(10 \mathrm{ml})$.

The mixture was stirred at $25^{\circ} \mathrm{C}$ for $4 \mathrm{~h}$. The resulting solid yellow was collected by filtration, and washed with n-Pentane then dried under vacuum. It was recrystallized from n-Pentane/ $\mathrm{CHCl}_{3}(1: 1)$ to afford yellow crystalline solid. with yield percent $86 \%$ (0.080g), M.p: $138-140^{\circ}$ C. Elemental analysis calculation for $\mathrm{C}_{31} \mathrm{H}_{28} \mathrm{NP}_{2} \mathrm{PdS}_{2} \mathrm{Cl}$ : C,53.96, $\mathrm{H}, 4.78, \mathrm{~N}, 2.12$ found $\mathrm{C}, 54.2, \mathrm{H}, 4.70, \mathrm{~N}, 2.04$ Molar conductivity in (DMSO): 35.2 $\Lambda\left(\mathrm{ohm}^{1} . \mathrm{cm}^{2} . \mathrm{mol}^{-1}\right)$. IR (KBr): 3053w, 2920w, $1438 \mathrm{~m}, 528 \mathrm{~m}, 1525 \mathrm{~s}, 997 \mathrm{w}, 426 \mathrm{vw} \mathrm{cm}^{-1} .{ }^{1} \mathrm{H}$ NMR $\left(\right.$ dmso-d $\left.^{6}\right) \quad \delta 7.29-7.77 \quad(\mathrm{~m}, \quad 20 \mathrm{H}), \delta$ 3.75(s, 2H), $\delta$ 2.95-3.07(m, 4H), $\delta 1.98(\mathrm{~m}$, 4H) ppm.

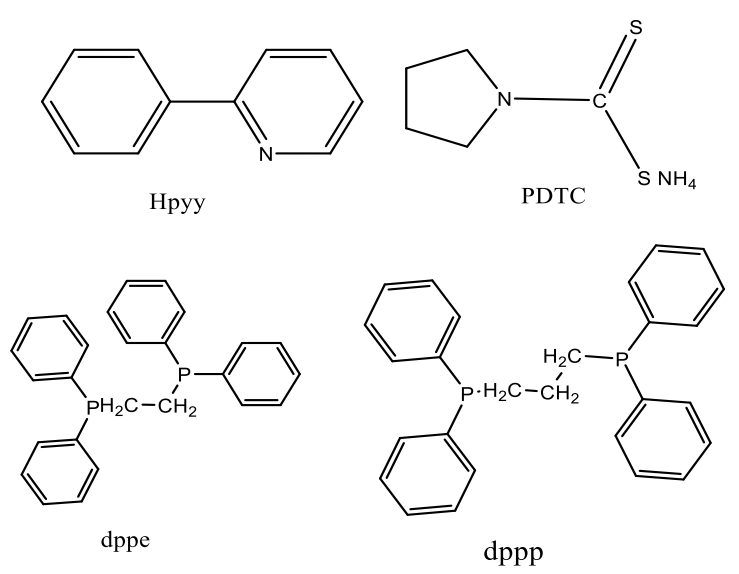

Fig.(1): 2-phenylpyridine (ppy), Pyrrolidinedi thiocarbamate (PDTC),

Bis(diphenylphosphino)ethane(dppe),

Bis(diphenyllp hosphino)propan(dppp).

\section{2-[Pd(PDTC)(ppy)]}

A [PDTC] $(0.022 \mathrm{~g}, 0.134 \mathrm{mmol})$ in $\mathrm{MeOH}$ $(10 \mathrm{ml})$ was added to $\left[\mathrm{Pd}_{2}(\mathrm{ppy})_{2}(\mu-\mathrm{Cl})_{2}\right]$ $(0.05 \mathrm{~g}, 0.134 \mathrm{mmol})$ dissolved in $\mathrm{CH}_{2} \mathrm{Cl}_{2}$ $(10 \mathrm{ml})$ The mixture was stirred at $30^{\circ} \mathrm{C}$ temperature for $4 \mathrm{~h}$. The resulting green yellow precipitate was collected by filtration, washed with $\mathrm{MeOH}$, leaving at room temperature for one day to dry. It was recrystallized from n-Pentane $/ \mathrm{CHCl}_{3}(1: 1)$ to afford yellow crystalline solid. with yield percent $91 \%$ $(0.050 \mathrm{~g}), \quad \mathrm{M} . \mathrm{p}: 237^{0} \mathrm{C}$. Elemental analysis calculation. for $\mathrm{C}_{16} \mathrm{H}_{12} \mathrm{~N}_{2} \mathrm{PdS}_{2}$ : C,47.29, $\mathrm{H}, 3.98, \mathrm{~N}, 6.84$ found $\mathrm{C}, 47.23$, H,3.96, N,6.89. Molar conductivity (DMSO):14.8 $\Lambda\left(\mathrm{ohm}^{-1} \cdot \mathrm{cm}^{2} \mathrm{~mol}^{-1}\right)$. IR (KBr): 3047w, 2913w, 1596w, 1566s, 1010w cm ${ }^{-1}$. ${ }^{1} \mathrm{H}$ NMR (dmso$\left.\mathrm{d}^{6}\right) \delta 8.25(\mathrm{~d}, \mathrm{H} 1), \delta 8.12(\mathrm{~d}, \mathrm{H} 4), \delta 8.06(\mathrm{t}, \mathrm{H} 2)$, $\delta$ 7.77(d, H5), $\delta 7.38(\mathrm{t}, \mathrm{H} 3), \delta 7.12(\mathrm{t}, \mathrm{H} 6)$, $\delta 7.07(\mathrm{t}, \mathrm{H} 7), \delta 6.92(\mathrm{~d}, \mathrm{H} 8), \delta 3.75(\mathrm{t}, 4 \mathrm{Ha}), \delta 2.02$ (p, 4H6) ppm.

\section{3-[Pd(PDTC) $)_{2}$ (dppe)]}

A Solution of (dppe) $(0.05 \mathrm{~g}, 0.13 \mathrm{mmol})$ in $\mathrm{CH}_{2} \mathrm{Cl}_{2}(10 \mathrm{ml})$ was add to a Solution of $[\mathrm{Pd}(\mathrm{P}$ DC $)_{2}$ ] $(0.053 \mathrm{~g}, 0.14 \mathrm{mmol})$ in $\mathrm{CH}_{2} \mathrm{Cl}_{2}(10 \mathrm{ml})$ [21].The mixture was mix at $25^{\circ} \mathrm{C}$ for $3 \mathrm{~h}$. The resulting solid yellow was collected by filtration, washed with n-Pentane and dried in vacuum. It was recrystallized from n- Pentane/ $\mathrm{CHCl}_{3}(1: 1)$ to afford yellow crystalline solid. yield $0.070 \mathrm{~g}, \quad 71 \%$. Elemental analysis calculation. for $\mathrm{C}_{36} \mathrm{H}_{32} \mathrm{~N}_{2} \mathrm{P}_{2} \mathrm{PdS}$ : $: \mathrm{C}, 54.33, \mathrm{H}$, 5.13, N,3.56 found C,54.23, H, 5.06, N, 3.51.

Molar conductivity (DMSO):

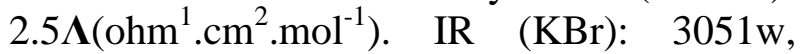
2948w, 1436m, 526m, 526m, 1529s, 1000w $412 \mathrm{vw} \mathrm{cm}^{-1}$. ${ }^{1} \mathrm{H}$ NMR (dmso-d $\left.{ }^{6}\right)$. $87.60-$ 7.74(m,20H), $\delta 3.71 \quad(\mathrm{~s}, 8 \mathrm{Ha}), \delta 2.98 \quad(\mathrm{~m}, 4 \mathrm{H})$, $\delta 2.03(\mathrm{~m}, 8 \mathrm{Hb})$ M.p: $134-136^{\circ} \mathrm{C}$.

\section{4-[Pd(PDTC $\left.)_{2}(\operatorname{dppp})\right]$}

A Solution of (dppp) $(0.06 \mathrm{~g} \cdot 0.15 \mathrm{mmol})$ in $\mathrm{CH}_{2} \mathrm{Cl}_{2}(10 \mathrm{ml})$ was add to a Solution of [Pd(PTDC $)_{2}$ ] [21]. $(0.053 \mathrm{~g}, 0.14 \mathrm{mmol})$ in $\mathrm{CH}_{2}$ $\mathrm{Cl}_{2}(10 \mathrm{ml})$ The all compound was stirred at $25^{\circ} \mathrm{C}$ temperature for $3 \mathrm{~h}$. The resulting solid yellow was collected by filtration and washed with n-Pentane and in vacuum dried. It was recrystallized from n-Pentane/ $\mathrm{CHCl}_{3}(1: 1)$ to afford yellow crystalline solid. yield $0.060 \mathrm{~g}$, $66 \%$. Elemental analysis calculation. for $\mathrm{C}_{37} \mathrm{H}_{34} \mathrm{~N}_{2} \mathrm{P}_{2} \mathrm{PdS} \mathrm{S}_{\varepsilon}: \mathrm{C}, 54.83, \quad \mathrm{H}, 5.23, \quad \mathrm{~N}, 3.51$, found $\mathrm{C}, 54.77, \mathrm{H}, 5.22, \quad \mathrm{~N}, 3.45$. Molar conductivity (DMSO): $12.8 \Lambda\left(\mathrm{ohm}^{-1} \cdot \mathrm{cm}^{2} \cdot \mathrm{mol}^{-1}\right)$. IR (KBr):3049w, 2948w, 1438m, 511w, $1517 \mathrm{~s}, 996 \mathrm{w}, 418 \mathrm{vw} \mathrm{cm}{ }^{-1} .{ }^{1} \mathrm{H}$ NMR (dmso-d ${ }^{6}$ ) 87.45-7.09 (m,20H), $\quad$ 33.64(m.8Ha), $\delta 3.00(\mathrm{~m} .4 \mathrm{H}), \quad \delta 1.95(\mathrm{~m}, 8 \mathrm{Hb})$ ppm.M.p:268$270^{\circ} \mathrm{C}$. 


\section{Results and Discussion}

\section{1. $[\operatorname{Pd}(\operatorname{PDTC})($ dppe $)] \mathrm{Cl}$}

In addition of one equivalents of Bis(diphenylphosphino)ethane (dppe) to a $\mathrm{CH}$ $\mathrm{Cl}_{3}$ solution of $[\mathrm{Pd}(\mathrm{PTDC}) \mathrm{Cl}][21]$ resulting yellow solid yield $86 \%$. In the infrared spectra Table (4) of this complex appeared two functional groups of $\boldsymbol{v}(\mathrm{P}-\mathrm{Ph}), \boldsymbol{v}(\mathrm{P}-\mathrm{C})$ in $(528$, $\left.1438 \mathrm{~cm}^{-1}\right)$, and it appeared strong absorption at the site $\left(1525 \mathrm{~cm}^{-1}\right)$ stretching back to the frequency range $\boldsymbol{v}(\mathrm{C}=\mathrm{N})$ for Pyrrolidine dithiocarbamate (PDTC), while the frequency range $(1332) \mathrm{cm}^{-1}$ back to $v(\mathrm{C}=\mathrm{S})$, and very weak shifted in $\left(426 \mathrm{~cm}^{-1}\right)$ back to $v(\mathrm{P}-\mathrm{Pd})$, The spectrum showed a weak shifted in $\left(997 \mathrm{~cm}^{-1}\right)$ back to $v$ (CSS) this shifted special for (PDTC) [27] Appearance of one single frequency for a group $v(\mathrm{CSS})$ evidence of the link (PDTC) bidentate in the complexes, [25].

${ }^{1} \mathrm{H}$ NMR spectrum Showed ${ }^{1} \mathrm{H}\left\{{ }^{31} \mathrm{P}\right\}$ NMR of the complex [Pd (PDTC)(dppe)] $\mathrm{Cl}$ Table(3) measured in the solvent DMSO multi-position signal at the shifted (1.98ppm) correspond to four protons of the value of integration of chemical and displacement this reference to the two sets of methylene protons $(4 \mathrm{Hb})$ to ring pyrrolidine, while multiple single in (3.01ppm) back to four protons of methylene protons $\left(\mathrm{CH}_{2}\right)_{2} \mathrm{P}$ of phosphine, also showed the spectrum mono signal at the site (3.75ppm) belonging to the four protons of methylene to ring of pyrrolidine (4Ha), multiple signal in the range (7.29-7.77)ppm back to the vinyl protons rings of phosphine [26] Fig.(2).

\section{2.[Pd(PDTC)(ppy)]}

The interaction between $\left(\mathrm{NH}_{4}(\mathrm{PDTC})\right)$ with the complex $\left[\mathrm{Pd}_{2}(\mathrm{ppy})_{2}(\mu-\mathrm{Cl})_{2}\right][21,23]$ afford yellow crystalline solid yield $91 \%$. In the infrared spectra Table (4) of this complex appeared storing shift in $1566 \mathrm{~cm}^{-1}$ back to the frequency range $v(C=N)$, middle shift in $(1485) \mathrm{cm}^{-1}$ refer to $\boldsymbol{v}(\mathrm{C}-\mathrm{N})$, while $1596 \mathrm{~cm}^{-1}$ back to frequency range of $v(C=C)$, the frequency range in $(1260) \mathrm{cm}^{-1}$ refers to $v(C=S)$, and very weak shifted in $(412) \mathrm{cm}^{-1}$ back to v(P-Pd), The spectrum showed a weak shift in $\left(1010 \mathrm{~cm}^{-1}\right)$ back to $v$ (CSS), evidence of the link (PDTC) bidentate in the complexes [21].

${ }^{1} \mathrm{H}$ NMR spectrum showed Table (3)
$1 \mathrm{H}\left\{{ }^{31} \mathrm{P}\right\} \mathrm{NMR}$ of the complex Penta signal at the $(2.08 \mathrm{ppm})$ back to four protons of methylene protons $(4 \mathrm{Hb})$ to ring pyrrolidine, while. The tripartite signal in $(3.75 \mathrm{ppm})$ back to four protons of methylene protons (4Ha) to ring pirolldan, The doublets signal in (6.92ppm) refer to $(\mathrm{H} 8)$, tripartite signal in $(7.07 \mathrm{ppm})$ to $(\mathrm{H} 7)$, tripartite signal in (7.12ppm) back to (H6), tripartite signal in (7.38ppm) to (H3), doublets signal in $(7.77 \mathrm{ppm})$ to $(\mathrm{H} 5)$, tripartite signal in (8.06ppm) to $(\mathrm{H} 2)$, doublets signal in $(8.12 \mathrm{ppm})$ to $(\mathrm{H} 4)$, doublets signal in $(8.35 \mathrm{ppm})$ to $(\mathrm{H} 1)$, all These signals back to proton of ring phenylpyridine [27] Fig.(3).

\section{3.[Pd(PDTC $)_{2}$ (dppe) $]$}

This complex was prepared from interaction between Bis(diph enylphosphino) ethane(dppe), with the complex [Pd(PDTC) $\left.)_{2}\right]$ [21] to afford yellow crystalline solid, yield 71\%. Pyrrolidine dithiocarbamate ligand behaves as mono dentate. IR spectra Table (4) of this complex appeared two functional groups of $\boldsymbol{v}(\mathrm{P}-\mathrm{Ph}), \boldsymbol{v}(\mathrm{P}-\mathrm{C})$ in $\left(526,1436 \mathrm{~cm}^{-1}\right)$, and it appeared strong absorption at the site $\left(1529 \mathrm{~cm}^{-1}\right)$ stretching back to the frequency range $\boldsymbol{v}(\mathrm{C}=\mathrm{N})$ for pyrrolidinedi thiocarbamate (PDTC), while the frequency range in (1249) $\mathrm{cm}^{-1}$ refer to $v(\mathrm{C}=\mathrm{S})$ The spectrum showed a two weak shifting in $\left(996-1000 \mathrm{~cm}^{-1}\right)$ back to $v$ (CSS) appearance of a single frequency for a group $v(\mathrm{CSS})$ evidence of the link (PDTC) behaves as mono dentate.

${ }^{1} \mathrm{H}$ NMR spectrum Table (3) showed multiple single in (2.03)ppm refer to eight protons $(8 \mathrm{Hb})$ to ring of pirolldan, while multiple single in (2.98ppm) back to four protons of methylene protons $\left(\mathrm{CH}_{2}\right)_{2} \mathrm{P}$ of phosphine also showed the spectrum mono signal at the site $(3.71 \mathrm{ppm})$, belonging to the eight protons for methylene protons to ring of pyrrolidine, multiple signal with in the range (7.60-7.74)ppm back to the twenty protons of vinyl protons rings phosphine Fig.(4).

\section{4. $\left[\operatorname{Pd}(\operatorname{PDTC})_{2}(\mathrm{dppp})\right]$}

This complex was prepared from interaction between Bis(diphenyllphosphino) Propan (dp pp) and $\left[\operatorname{Pd}(\mathrm{PDTC})_{2}\right]$ complex [21]. The resulting was yellow crystalline solid of $\left[\operatorname{Pd}(\mathrm{PDTC})_{2}(\mathrm{dppp})\right]$ yield $66 \%$. pyrrolidine 
dihtiocarbamate ligand behaves as mono dentate. IR spectra Table (4) of this complex appear two functional groups of $\boldsymbol{v}(\mathrm{P}-\mathrm{Ph})$, $\boldsymbol{v}(\mathrm{P}-\mathrm{C})$ in $\left(511,1438 \mathrm{~cm}^{-1}\right)$, and it appeared strong absorption at the site $\left(1517 \mathrm{~cm}^{-1}\right)$ stretching back to the frequency range $v(C=N)$ for Pyrrolidinedi thiocarbamate (PDTC), while the frequency range in $(1328) \mathrm{cm}^{-1}$ refer to $v(C=S)$, and very weak shifting in $\left(426 \mathrm{~cm}^{-1}\right)$ back to v(P-Pd), The spectrum showed a two weak shifting in $\left(968,1000 \mathrm{~cm}^{-1}\right)$ back to $v(\mathrm{CSS})$ and the emergence of a single frequency for a group $v(\mathrm{CSS})$ evidence of the link (PDTC) behaves as mono dentate [25].

${ }^{1} \mathrm{H}$ NMR spectrum Table (3) Showed multiple single in (1.95)ppm refer to ten protons eight for $(8 \mathrm{Hb})$ to ring of pyrrolidine, and two protons of the methylene group distant from the phosphorus atom $\left(\mathrm{CH}_{2}\right) \mathrm{CH}_{2}$ of phosphine, while multiple single in $(3.00 \mathrm{ppm})$ back to four protons of methylene protons $\left(\mathrm{CH}_{2}\right)_{2} \mathrm{P}$ of phosphine also showed the spectrum mono signal at the site $(3.64 \mathrm{ppm})$, belonging to the eight protons for methylene protons to ring of pyrrolidine, multiple signal in the range (7.45-7.69)ppm, back to the vinyl protons rings phosphine [26] (Fig 5).

\subsection{Electronic Spectra of [PdL1L2]Complex}

Three different absorbs appeared in three different locations for each prepared complexes which are assigned to ${ }^{1} \mathrm{~A}_{1} \mathrm{~g} \rightarrow{ }^{1} \mathrm{~B}_{1} \mathrm{~g}$ and ${ }^{1} \mathrm{~A}_{1} \mathrm{~g} \rightarrow{ }^{1} \mathrm{E}_{1} \mathrm{~g}$ were the third absorbency refer to correspond to $\mathrm{L} \rightarrow \mathrm{PdCT}$ transitions [27], the position of these bands are in good agreement with that reported for square planer geometry [24,28]. In addition the measured magnetic moment for this complex was found to be 0.0B.M, while the conductance measurements indicate that the complex was to be nonionic except the first complex, $[\mathrm{Pd}(\mathrm{PD}$ TC)(dppe)]Cl was ionic Table (2).

\section{Conclusion}

In this paper, we succeeded to prepare new four mono nuclear complexes based on another complexes by replacement ligands, the (PDTC) ligand behaves in the prepared complexes as a bidentate and coordinate through two sulfur atoms to metalion, The prepared tertiary phosphines complexes showed that the tertiary phosphines are coordinated as a bidnetate via two phosphor (P) atoms, with ppy ligands is metelated and coordinated as chelate through the carbon atom of the phenyl ring and the $\mathrm{N}$ atom of the pyridine ring that make the new complexes more stable, all prepared complexes showed square planer shape and all complexes have been characterized by spectroscopic methods, in addition to elemental analysis(C.H.N) and conductivity measurement.

Table (1)

Elemental analyses and some other data of the complexes.

\begin{tabular}{|c|c|c|c|c|c|c|c|c|}
\hline \multirow[t]{2}{*}{ Complexes } & \multirow{2}{*}{$\begin{array}{l}\text { Molecular } \\
\text { formula }\end{array}$} & \multirow{2}{*}{$\underset{(\mathrm{g} / \mathrm{mol})}{\mathrm{M} . \mathrm{W}}$} & \multirow[t]{2}{*}{ Color } & \multirow[t]{2}{*}{ M.P. ${ }^{\circ} \mathrm{C}$} & \multirow{2}{*}{$\begin{array}{c}\text { Yield } \\
\%\end{array}$} & \multicolumn{3}{|c|}{$\begin{array}{l}\text { Elemental analysis } \\
\text { Found(cal)\% }\end{array}$} \\
\hline & & & & & & $\bar{C}$ & $\mathbf{H}$ & $\mathbf{N}$ \\
\hline $\begin{array}{c}{[\mathrm{Pd}(\mathrm{PDTC})(\mathrm{dppe})]} \\
\mathrm{Cl}\end{array}$ & $\mathrm{C}_{31} \mathrm{H}_{28} \mathrm{NP}_{2} \mathrm{PdS}_{2} \mathrm{Cl}$ & 682.52 & $\begin{array}{c}\text { Pale } \\
\text { Yellow }\end{array}$ & $138-140$ & 86 & $\begin{array}{c}53.96 \\
(54.23) \\
\end{array}$ & $\begin{array}{l}4.78 \\
(4.70) \\
\end{array}$ & $\begin{array}{c}2.12 \\
(2.04) \\
\end{array}$ \\
\hline$[\mathrm{Pd}(\mathrm{PDTC})(\mathrm{ppy})]$ & $\mathrm{C}_{16} \mathrm{H}_{12} \mathrm{~N}_{2} \mathrm{PdS} \mathrm{S}_{2}$ & 402.82 & $\begin{array}{l}\text { Pale } \\
\text { Yellow } \\
\end{array}$ & $237-239$ & 91 & $\begin{array}{c}47.29 \\
(47.23) \\
\end{array}$ & $\begin{array}{c}3.98 \\
(3.96) \\
\end{array}$ & $\begin{array}{c}6.84 \\
(6.89) \\
\end{array}$ \\
\hline$\left[\mathrm{Pd}(\mathrm{PDTC})_{2}(\mathrm{dppe})\right]$ & $\mathrm{C}_{36} \mathrm{H}_{32} \mathrm{~N}_{2} \mathrm{P}_{2} \mathrm{PdS} \mathrm{s}_{\varepsilon}$ & 789.29 & $\begin{array}{l}\text { Pale } \\
\text { Yellow } \\
\end{array}$ & $134-136$ & 70 & $\begin{array}{c}54.33 \\
(54.23) \\
\end{array}$ & $\begin{array}{r}5.13 \\
(5.06) \\
\end{array}$ & $\begin{array}{c}3.56 \\
(3.51) \\
\end{array}$ \\
\hline$\left[\mathrm{Pd}(\mathrm{PDTC})_{2}(\mathrm{dppp})\right]$ & $\mathrm{C}_{37} \mathrm{H}_{34} \mathrm{~N}_{2} \mathrm{P}_{2} \mathrm{PdS} \mathrm{S}_{\varepsilon}$ & 802.32 & $\begin{array}{l}\text { Pale } \\
\text { Yellow } \\
\end{array}$ & $268-270$ & 66 & $\begin{array}{c}54.83 \\
(54.77) \\
\end{array}$ & $\begin{array}{r}5.23 \\
(5.22) \\
\end{array}$ & $\begin{array}{c}3.51 \\
(3.45) \\
\end{array}$ \\
\hline
\end{tabular}


Table (2)

Decomposed Electronic spectra, conductance in DMOS solvent and magnetic moment (B.M) for metal complex.

\begin{tabular}{|c|c|c|c|c|c|}
\hline Complexes & $\lambda(\mathrm{nm}) \mathrm{cm}^{-1}$ & $\begin{array}{c}\text { Assignment } \\
\text { Bands for all complexes } \\
\end{array}$ & $\begin{array}{l}\text { ueff. } \\
\text { B.M }\end{array}$ & $\begin{array}{c}\text { Moler. cond } \\
\left(\mathrm{ohm}^{-1} \cdot \mathrm{cm}^{2} \cdot \mathrm{mol}^{-1}\right) \Lambda \\
\end{array}$ & $\begin{array}{l}\begin{array}{c}\text { Suggested } \\
\text { geometry }\end{array} \\
\end{array}$ \\
\hline$[\mathrm{Pd}(\mathrm{PDTC})(\mathrm{dppe})] \mathrm{Cl}$ & $246,316,381$ & \multirow{4}{*}{$\begin{array}{c}{ }^{1} \mathrm{~A}_{1} \mathrm{~g} \rightarrow{ }^{1} \mathrm{~B}_{1} \mathrm{~g}^{1} \\
\mathrm{~A}_{1} \mathrm{~g} \rightarrow{ }^{1} \mathrm{E}_{1} \mathrm{~g} \\
\mathrm{~L} \rightarrow \mathrm{PdCT}\end{array}$} & \multirow{4}{*}{0.0} & 35.2 & \multirow{4}{*}{ Square planer } \\
\hline$\left[\mathrm{Pd}(\mathrm{PDTC})_{2}(\mathrm{dppe})\right]$ & $362,307,522$ & & & 2.5 & \\
\hline$\left[\mathrm{Pd}(\mathrm{PDTC})_{2}(\mathrm{dppp})\right]$ & $262,295,582$ & & & 12.8 & \\
\hline$[\mathrm{Pd}(\mathrm{PDTC})(\mathrm{ppy})]$ & $250,320,495$ & & & 14.8 & \\
\hline
\end{tabular}

Table (r)

${ }^{1}$ HNMR data for complexes.

\begin{tabular}{|c|c|c|c|c|}
\hline Complexes & $\begin{array}{c}\delta H \text { rings } \\
\text { ppy }\end{array}$ & $\begin{array}{c}\text { סH rings } \\
\text { (Phos.) } \\
(\text { ppm) }\end{array}$ & $\begin{array}{c}\boldsymbol{\delta} \text { (PDTC) } \\
\text { H a } \\
\text { H b } \\
(\mathrm{ppm}) \\
\end{array}$ & $\begin{array}{c}\boldsymbol{\delta} \text { (Phos.) } \\
\mathrm{CH}_{2} \\
\mathrm{CH}_{2} \\
(\mathrm{ppm}) \\
\end{array}$ \\
\hline$[\mathrm{Pd}(\mathrm{PDTC})(\mathrm{dppe})] \mathrm{Cl}$ & - & 7.29-7.77 m & $\begin{array}{c}1.88-2.09 \mathrm{~m} \\
3.75 \mathrm{~s}\end{array}$ & $2.95-3.07 \mathrm{~m}$ \\
\hline$\left[\operatorname{Pd}(\mathrm{PDTC})_{2}(\mathrm{dppe})\right]$ & - & $7.60-7.74 \mathrm{~m}$ & $\begin{array}{c}1.97-2.09 \mathrm{~m} \\
3.71 \mathrm{~s}\end{array}$ & $\begin{array}{c} \\
2.95-3.00 \mathrm{~m}\end{array}$ \\
\hline$\left[\mathrm{Pd}(\mathrm{PDTC})_{2}(\mathrm{dppp})\right]$ & - & $7.45-7.69 \mathrm{~m}$ & $\begin{array}{l}1.87-2.02 \mathrm{~m} \\
3.52-3.77 \mathrm{~m}\end{array}$ & $\begin{array}{c}1.87-2.02 \mathrm{~m} \\
3.00 \mathrm{~s}\end{array}$ \\
\hline [Pd(PDTC)(ppy)] & $\begin{array}{l}\mathrm{H}_{1}=8.35 \mathrm{~d} \\
\mathrm{H}_{4}=8.12 \mathrm{~d} \\
\mathrm{H}_{2}=8.06 \mathrm{t} \\
\mathrm{H}_{5}=7.77 \mathrm{~d} \\
\mathrm{H}_{3}=7.38 \mathrm{t} \\
\mathrm{H}_{6}=7.12 \mathrm{t} \\
\mathrm{H}_{7}=7.07 \mathrm{t} \\
\mathrm{H}_{8}=6.92 \mathrm{~d}\end{array}$ & - & $\begin{array}{l}2.08 \mathrm{p} \\
3.75 \mathrm{t}\end{array}$ & - \\
\hline
\end{tabular}

Table ( $\leq)$

The most important bands $\left(\mathrm{cm}^{-1}\right)$ of the infrared spectra of the complexes.

\begin{tabular}{|c|c|c|c|c|c|c|c|c|}
\hline \multirow{2}{*}{ Complexes } & \multicolumn{2}{|c|}{$\overline{v(C-H)}$} & \multicolumn{2}{|c|}{ diphosphin } & \multirow{2}{*}{$v(C=N)$} & \multirow{2}{*}{$v(\mathrm{CSS})$} & \multirow{2}{*}{$v(C=S)$} & \multirow{2}{*}{$v(P-P d)$} \\
\hline & Ar & Alph & $v(P-C)$ & v(P-Ph) & & & & \\
\hline$[\mathrm{Pd}(\mathrm{PDTC})(\mathrm{dppe})] \mathrm{Cl}$ & $3053 w$ & $2925 \mathrm{w}$ & $538 \mathrm{~m}$ & $1431 \mathrm{~m}$ & $1525 \mathrm{~s}$ & $997 \mathrm{~W}$ & $1332 \mathrm{w}$ & 426 \\
\hline$\left[\mathrm{Pd}(\mathrm{PDTC})_{2}(\mathrm{dppe})\right]$ & $3051 \mathrm{w}$ & 2948 & $526 \mathrm{~m}$ & $1436 \mathrm{~m}$ & $1529 \mathrm{~s}$ & $996 \mathrm{w}$ & $1249 \mathrm{w}$ & 412 \\
\hline$\left[\mathrm{Pd}(\mathrm{PDTC})_{2}(\mathrm{dppp})\right]$ & $3049 \mathrm{w}$ & $2948 w$ & $511 \mathrm{~m}$ & $1438 \mathrm{~m}$ & $1517 \mathrm{~s}$ & $968 \mathrm{w}$ & $1328 \mathrm{~m}$ & 418 \\
\hline$[\mathrm{Pd}(\mathrm{PDTC})(\mathrm{ppy})]$ & $3047 \mathrm{w}$ & $2913 w$ & 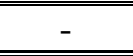 & 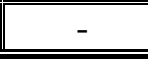 & $1566 \mathrm{~s}$ & $1010 \mathrm{w}$ & $1260 \mathrm{~m}$ & - \\
\hline
\end{tabular}




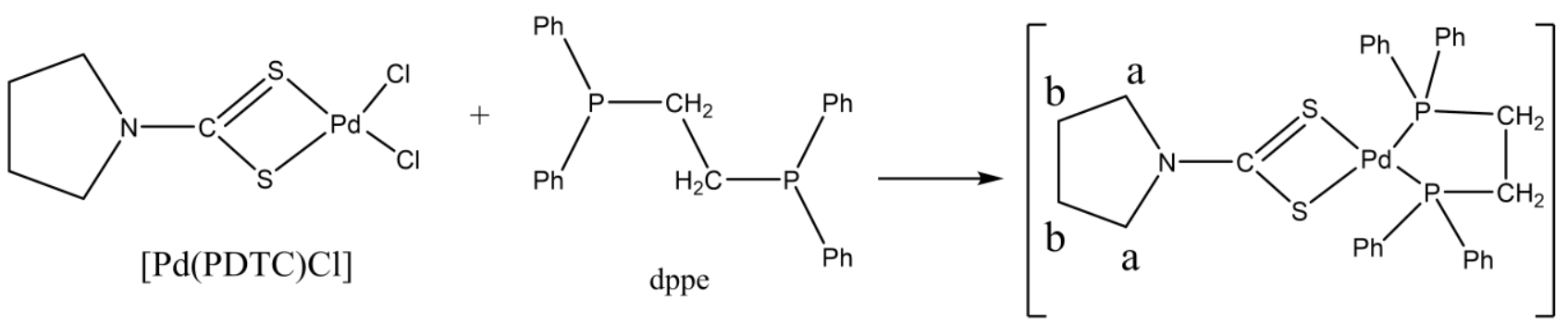

[Pd(PDTC)(dppe)]Cl<smiles></smiles>

$[\operatorname{Pd}(\mathrm{ppy})(\mu-\mathrm{Cl})]$<smiles>NSC(=S)N1CCCC1</smiles>

(PDTC)<smiles>CC(C)[R17](=O)C(C)C</smiles><smiles></smiles>

$\left[\mathrm{Pd}(\mathrm{PDTC})_{2}\right]$

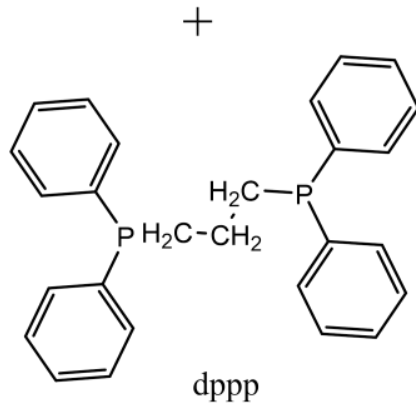<smiles>c1ccc(P(CCP(c2ccccc2)c2ccccc2)c2ccccc2)cc1</smiles>
dppe

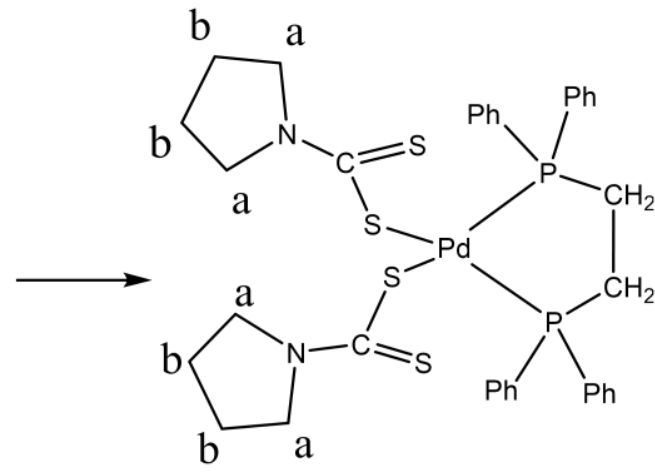

$\left[\operatorname{Pd}(\operatorname{PDTC})_{2}(\right.$ dppe $\left.)\right]$

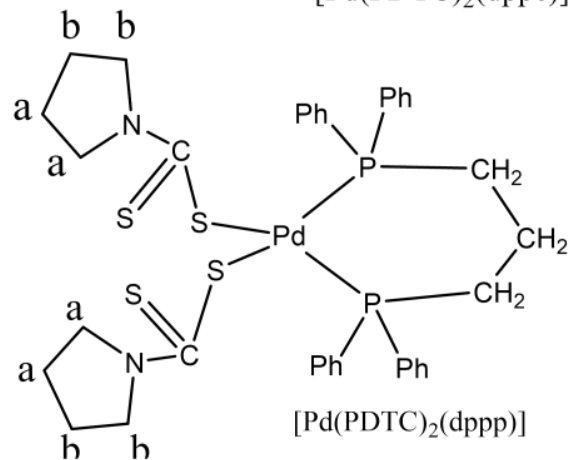

Scheme (1) : Reactions between mixed ligands and complexes. 


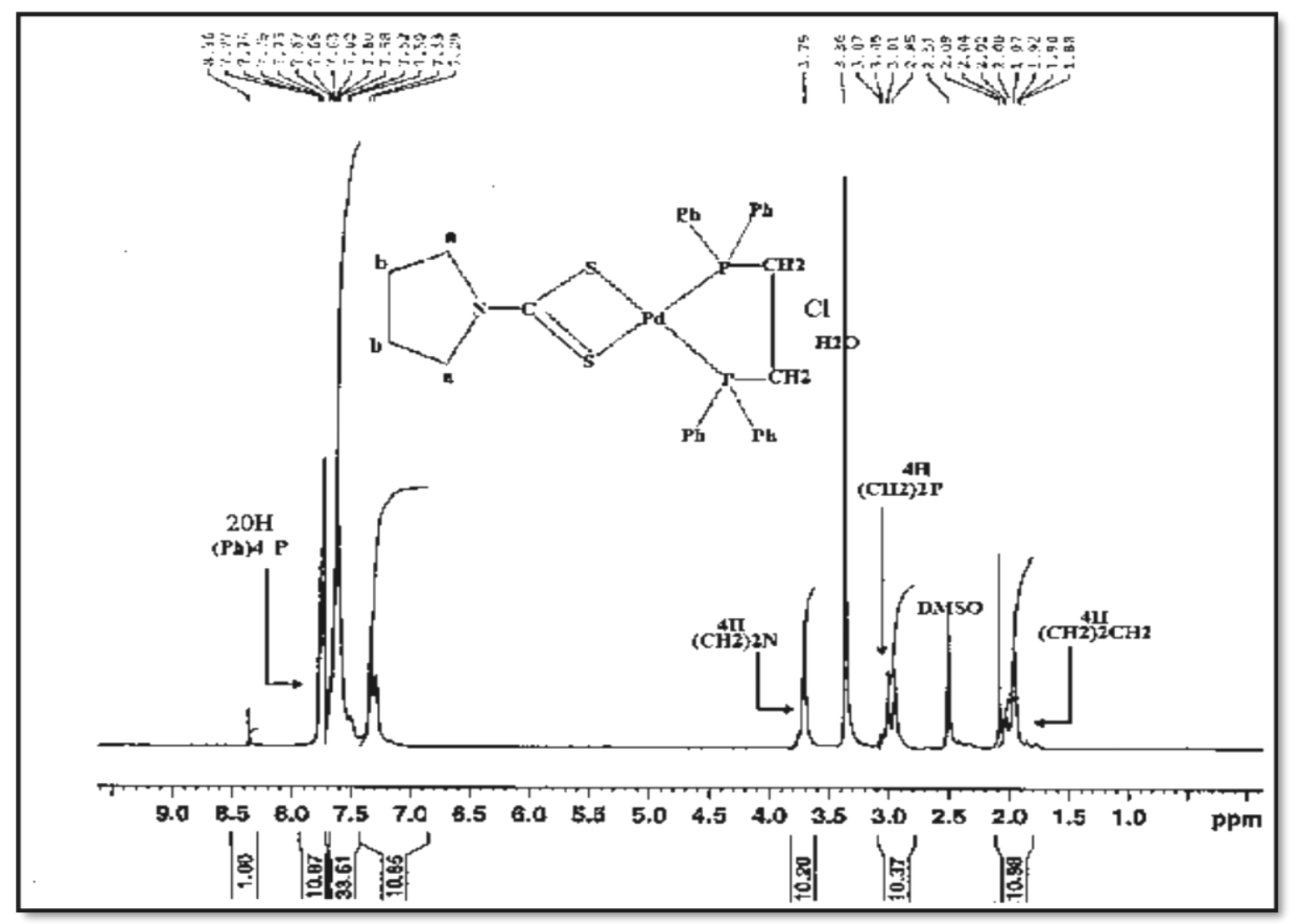

Fig.(2): ${ }^{1}$ HNMR spectra of the [Pd(PDTC)(dppe)]Cl.

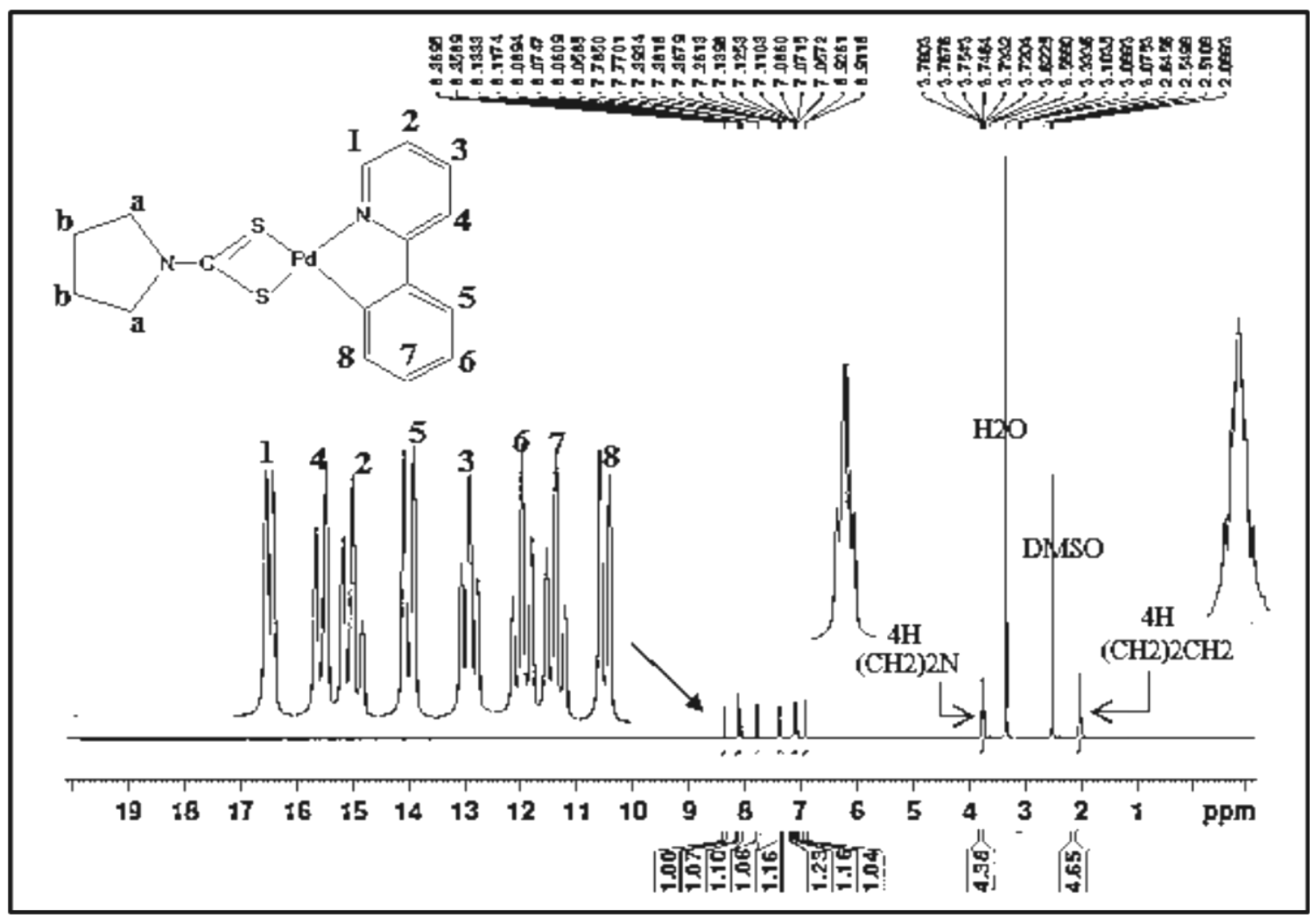

Fig.(3): ${ }^{1}$ HNMR spectra of the [Pd(PDTC)(ppy)]. 


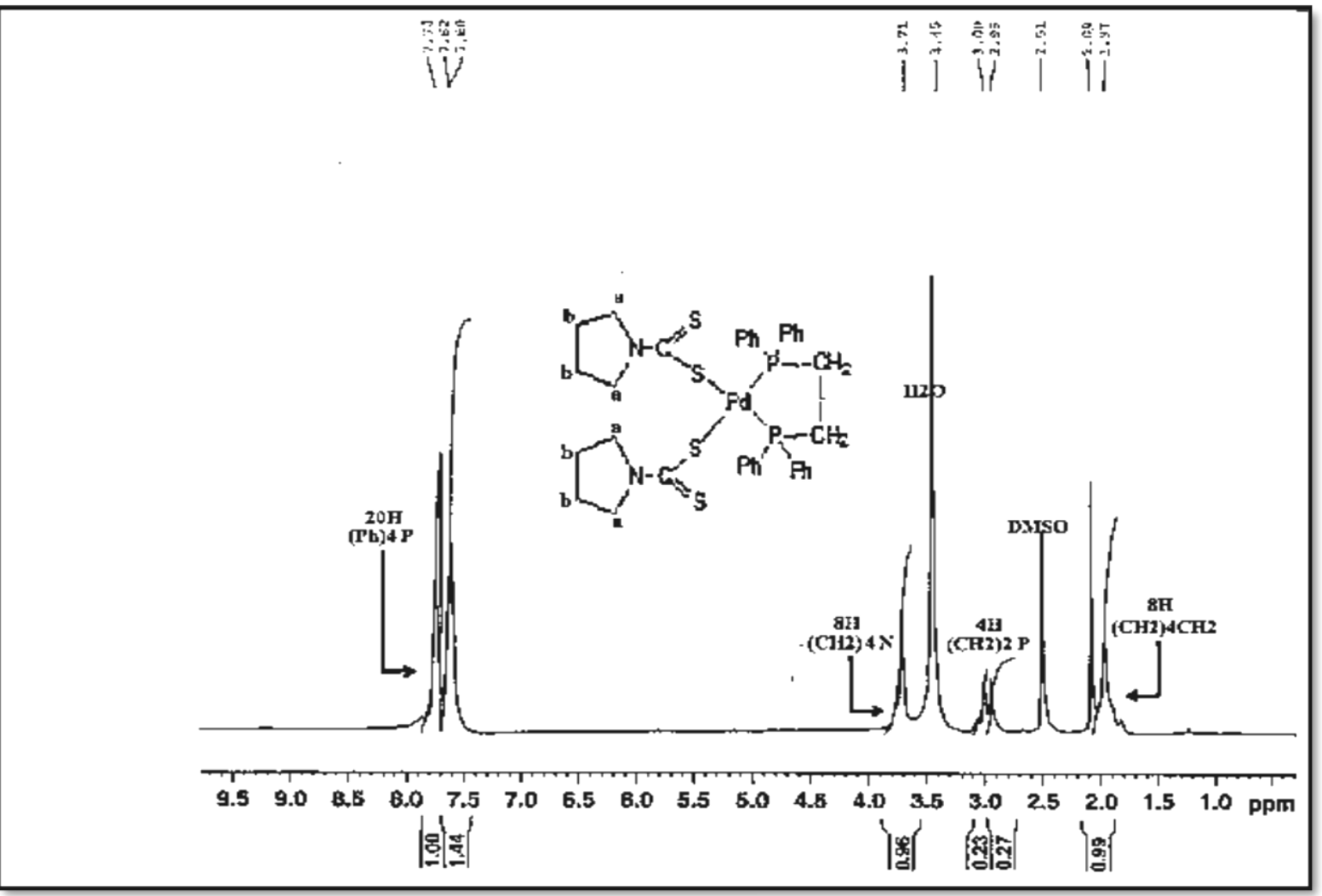

Fig.(4): ${ }^{1} \mathrm{HNMR}$ spectra of the $\left[\mathrm{Pd}(\mathrm{PDTC})_{2}(\mathrm{dppe})\right]$.

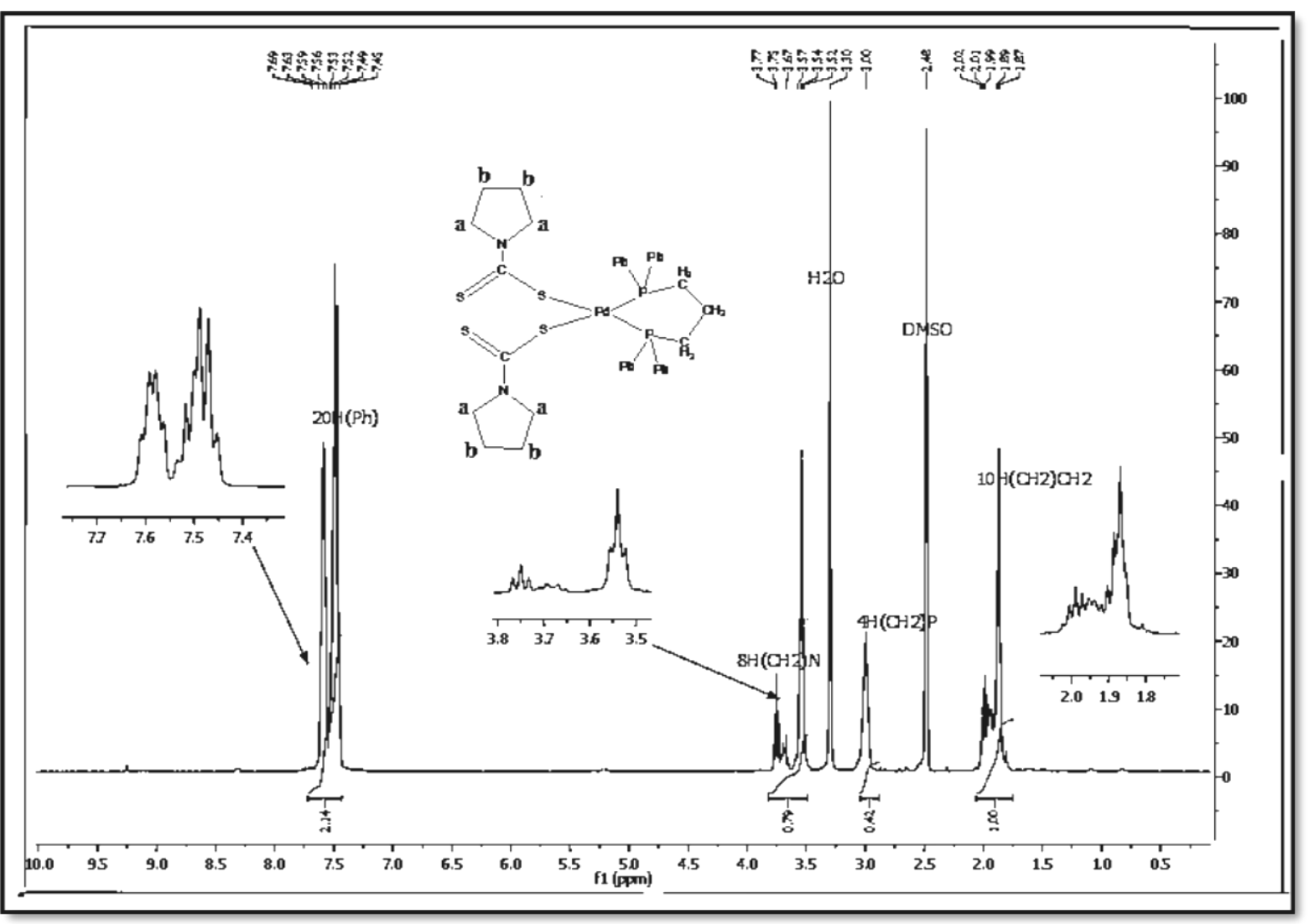

Fig. (5): ${ }^{1}$ HNMR spectra of the $\left[\mathrm{Pd}(\mathrm{PDTC})_{2}(\mathrm{dppp})\right]$. 


\section{Acknowledgments}

We like to thank the department of chemistry University of Tikrit for support of this work and directorate general education of Diyala, best thank for professor Subhi A. Al-Jibori, Special thanks to all members in the journal of Al-Nahrain University Journal of Science.

\section{References}

[1] Daisei M., Yuki K., NaoKo E., and Takashi S., "Thujaplicin-copper chelates inhibit replication of human influenza viruses", Antiviral Res., 39(2), 89-100, 1998.

[2] Takizawa T., Tatematsu C., and Ohashi K., "Pecruitment of apoptotic Cysteine prot eases (caspases) in influenza Virusinduced cell death", microbiology Immunology., 43(3), 245-52, 1999.

[3] Frear D., "Chemistry of Fungicides", J.Indian., 293 - 300, 1955.

[4] Garg D.M., "Syntheses of Thiocarb amates", J. Indian. Chem. Soc., 42(6), 415420, 1965.

[5] Ansari M.N., Jain, M. C., and Malik W. U., "Studies on The complexes of Fe (III), $\mathrm{Co}$ (III), $\mathrm{Ni}$ (II) and $\mathrm{Cu}$ (II) with potassium normal-butyl xanthate", J. Indian. Chem. Soc., 57(9), 861-866, 1980.

[6] Arora A., and Arora C., "Synthesis of Transition Metal Diethyldithiocarbamates and Their Effect on Nodulation and Other Growth Characters in Mungbean, Vigna radiata"., Asian. J. Chem., 15(1), 144-147, 2003.

[7] Barrientos C. F., Carbacho H., Contreras J. G., and Lagos G., "Some new polimeric complexes of ethylenebisdithiocarbamate", J. Inorg. Nucl. Chem., 40(5), 926-980, 1978.

[8] Garg D. M., "Syntheses of Thiocarb amates", J. Indian. Chem., 42(5),339-344, 1965.

[9] Malik W., Bembi R., and Bhardwaj V. K., "Metal-complexes with sulfur donor ligands preparation and Characterization of some Mixed Ligands complexes", J. Indian. Chem. Soc., 57(92), 35-39, 1980.

[10] Peter J. H., Kenneth K., Julie S. N., and Derek A. T., "Trimethylplatinum (IV) complexes of dithiocarbamato ligands: an experimental NMR study on the barrier to C$\mathrm{N}$ bond rotation", J. Chem. Soc. Dalton Trans., 30(3), 1349-1356, 2000.

[11] Phalguni G., Sutapa G., Osmond J.D., and Fatih M.U., "Structural and biological characterization of a novel spermicidal vanadium (IV) complex: $\operatorname{Bis}(\pi$-cyclopentadie nyl)-N,N-diethyl dithiocarbamato vanad ium(IV)tetrafluoroborate, [VCp2(DeDtc)](B F4)"., J. Inorg. Biochem., 72(2), 89-98, 1998.

[12] Cox N. J. and Kawaoka Y. T., "Influenza in Topely and will Son's microbiology and microbial infections", 9nt Ed. (collier, L., Balows, A. and Sussman, M., Eds), Aronld, London, U.K, 256-258, 1998.

[13] Noboru U., Kunio O., Toshio B., Bo Y., Toshio Y., "Effect of antioxidants on apoptosis induced by influenza virus infection: inhibition of viral gene replication and transcription with pyrrolidine dithiocarbamate"., Antiviral Re, 56(3), 207-217, 2002.

[14] Levason W., Mcauliffe C.A., "Transition Metal Complexes Containing Bidentate Phosphine Ligands"., J.Advances in Inorganic Chemistry and Radiochem istry., 14,73-253, 1972.

[15] Laith A., Mohammad E., Mohammad H., Helmar G., Wolfgang W., "Synthesis and characterization of platinum and palladium pyrrolidinedithiocarbamate complexes"., Transition. Met. Chem., 38(4), 377-383 2013.

[16] Masters C., "Homogenous transition metal catalysis"., Champ and Hall publishers, London, 350-353, 1981.

[17] ShuMin $H$ and ShinGuang D., "Metal-Metal-Bond-Assisted Substitution Reaction of a Heterobimetallic PhosphidoBridged Mo-Fe Complex"., Polyhedron, 17 (6), 1151-1154, 1998.

[18] Heal.G.R., Laye.P.G., Price., "Thermal Analysis and Calorimetry", The Royal Society of chemistry publishers, farnham and surrey UK., 361-370, 2002.

[19] Michael E. P., Donald G. D, George W. K., Joel V. T., and Robert E. L., "Studies of Inhibitor Binding to Escherichia coli Purine Nucleoside Phosphorylase Using the Transferred Nuclear Overhauser Effect and Rotating-Frame Nuclear Overhauser 
Enhancement"., J.Organometallic., 33 (24), 7547-7559, 1994.

[20] Tomasz. P, Daria. N, Jan V., Radek. M and L. Pazderski., "Dimeric Pd(II) and Pt(II) chloride organometallics with 2phenyl pyridine and their solvolysis in dimethylsulfoxide"., J. Organometallic Chem istry., 759, 58-66, 2014.

[21] Leszek P., Radek M., JanV., Daria N., and Tomasz P., "Dimeric Pd(II) and Pt(II) chloride organometallics with 2phenylpyridine and their solvolysis in dimethylsulfoxide"., J. Organometallic Chem., 759, 58-66, 2014.

[22] Ninad G., Amey W., Sandip D., Vimal K. "Synthesis, structures and spectroscopic properties of platinum complexes containing orthometalated 2phenylpyridine", J.Organo metallic.Chem, 695, 1237- 1245, 2010.

[23] Subhi A. A., Hayfa M. G, Mousa S. A., Sucharita B., Shishir G., "Synthesis and molecular structures of palladium(II) metalated 2-phenylpyridine complexes $[\mathrm{PdCl}$ (pyC6H4)L] containing amino or acet ylamino-pyridine co-ligands"., Inorganica C himica Acta., 450, 50-56, 2016.

[24] Giuseppina F., Sergio S., Diego M., "Pyrrolidine dithiocarbamates of Pd(II)",, J. Inorg. Chimica Acta., 358(4), 971 -980, 2005.

[25] Farkhanda S., Amin B., Marcel G., Gia nluca C., Ulrich F., "In vitro assessment of cytotoxicity, anti-inflammatory, antifungal properties and crystal structures of metallacyclicpalladium(II)complexes"., J. Organometallic Chemistry., 695(3), 315322, 2010.

[26] Diego M.,Cristina M.,Valentina G., "Synthesis, characterization and cytotoxic activity of palladium (II) dithiocarbamate complexes with $\alpha, \omega$-diamines"., J. Inorg Chim Acta., 376,(1) 574-580, 2011.

[27] Simon J., Richard T., Bernard L., "Complexes of platinum (II) and palladium (II) with hybrid phosphine-phosphine oxide ligands of type $\mathrm{Ph}_{2} \mathrm{P}\left(\mathrm{CH}_{2}\right)_{n} \mathrm{P}\left(\mathrm{CH}_{2}\right) \mathrm{Ph}_{2}$ ( $n=1,2,3$, or 4$) "$., J. Organomet. Chem"., 325(2), 285-292, 1987.
[28] Nekamoto K., "Infra Red and Raman Spectra of Inorganic and Coordination Compounds"., 6Sixth., John Wiley and Sons, Inc., Simultaneously Canada., 192213, 2009. 